\title{
Disposition Event Start Date Time
}

National Cancer Institute

\section{Source}

National Cancer Institute. Disposition Event Start Date Time. NCI Thesaurus. Code C83251.

The date and time a disposition event began. 